\title{
RESIDENTS’ SUPPORT IN MAJOR LOCAL EVENTS: LEEDS PRIDE
}

\author{
NIKOLAOS PAPPAS \\ London School of Hospitality and Tourism, University of West London, London, UK
}

\begin{abstract}
This article examines the extent to which community participation and perceived impacts have an influence on residents' support of major events, more specifically, the Leeds Pride celebration. The research examines the perspectives of 400 Leeds permanent residents. The study tests a structural equation model, which has its theoretical basis in social exchange theory. It examines the constructs of community participation, perceived positive and negative impacts, and community support, including the actual participation of locals in the event. The findings reveal that the actual participation of locals to decision making influences their perspectives on community participation. The support is influenced by views of the perceived impacts, whereas community participation has no direct influence. Conversely, the community involvement in decision making considerably influences the perceived benefits and costs of the event, acting as a moderator, whereas the willingness of support is connected with the community's participation. Finally, the article discusses theoretical and managerial aspects for major event planning and development.
\end{abstract}

Key words: Local events; Tourism; Social exchange theory (SET); Community engagement; Perceived impacts; Community support

Introduction

Events are one of the more perceptible influences on tourism growth, whereas tourism is the leading growth sector in international service trade (Fourie \& Gallego, 2011). Recently, major events have been engines for leisure tourism development in general, and collaborative tourism development in particular, within the hosting areas (Lamberti, Noci, Guo, \& Zhu, 2011) because they are "capable of generating great economic benefit and promoting the development of related industries” (Peng,
Cheng, \& Qin, 2013, p. 245). The hosting of events has an impact on long-term tourism, and it benefits the local economy and its host population by job creation, income generation, investment attraction, extension of the tourist season, destination promotion, and creation of tax revenues (Deccio \& Baloglu, 2002). Thus, the participation of all stakeholders with special reference to host community is required (Kruger \& Heath, 2013). Still, major event decision making and planning involves a predominantly political planning approach, which allows little input from local residents, whereas the more 
democratic approach to event planning is surely more difficult to implement. As a result, destinations adopt it less frequently, or adopt it in name only (Haxton, 1999).

The literature includes several studies focusing on locals' perceptions of the impacts of major events and on residents' support in relation to perceived positive and negative impacts (Gursoy \& Kendall, 2006). With a carefully crafted and reflexive process of tourism planning, stakeholders and residents can have a profound influence on decision making (Grant, 2004). Still, the extent to which community participation can affect the overall support of these events is limited, and further investigation of the importance of local perceptions in decision making is needed.

Most of the times, locals want to participate in decision making, but this opportunity is rarely provided in an effective manner (Zhao \& Ritchie, 2008). Thus, decision makers overcome this exclusion by legislating for community participation within the management process of the destination (Van Niekerk, 2014). In the case of Leeds, the city council has formulated three levels for community participation: (1) corporate engagement and consultation activities, (2) service-based activities, and (3) community-driven engagement (Leeds City Council, 2006). Even so, in several cases the interpretation of locals' participation is given by their engagement on the event itself, either having an active role or participating as attendants declaring their support through their presence (Stokes, 2008). Thus, the examination of community participation needs to take under consideration all the aspects presented above.

This article examines the extent to which community participation (involvement in decision making and engagement during the event itself) and perceived impacts affect residents' support of major events and, more specifically, the Leeds Pride celebration. Through the creation of a structural model, it demonstrates the extent of the influence of community participation and the impact on community support for Leeds Pride. This study contributes to the theoretical domain in four ways. The first contribution is the use of social exchange theory (SET) — something that is substantially used for mega-events (Pappas, 2014) but has not sufficiently been implemented in major local events. Although several studies discuss the support of locals for major events and the development of positive and negative impacts (Gursoy \& Kendall, 2006), the influence of community participation is underreported. Thus, the second contribution is the relationship of community participation and impacts with residents' support, also connected with the third and main contribution of the study, which relates to the inclusion of the community participation construct in the model. It finally contributes to the literature through the investigation of residents' participation in decision making, focusing in particular on Leeds Pride.

\section{Tourism in Leeds and Leeds Pride}

Leeds is the third largest city in the UK after London and Birmingham, with a population exceeding 700,000 inhabitants (City Mayors, 2012). Since the 1970s, the Local Authority has diversified the city's employment base, due to the decline of its traditional industries, by rapidly developing its tourism industry and including the development and promotion of its image as a destination (Stevenson, Airey, \& Miller, 2008). Tourism's economic contribution is important to the city. The tourism and hospitality industry directly employs approximately 30,000 people (VisitBritain, 2013), and when combined with leisure and business tourism, it supports more than 44,000 jobs and is worth more than $£ 1$ billion to the Leeds economy, placing tourism in a key role by raising the profile of the city both within the UK and abroad, through the attraction of business and investment (Leeds City Council, 2009).

Leeds Pride is a celebration of the diversity of lesbian, gay, and bisexual communities (Leeds Pride, 2012). It is held every year, usually in the first weekend in August, in a central party spot, and the parade finishes its journey in the city center (Virtual Tourist, 2012). Leeds Pride has grown within the last 7 years to be the largest major event in Leeds (Leeds Pride, 2012), having more than 30,000 participants (Carmody, 2012) and directly bringing more than $£ 2$ million within 2 days into the city's economy (Leeds Pride, 2012). The benefits of Leeds Pride are very important, especially during the current recession where the future for local business is uncertain. It faces a decline in sales and orders (Leeds City Region, 2012) and suffers from workforce reduction, having lost tens of thousands 
of jobs during the crisis, while several of its communities have been cut off from employment and the wealth of a growing city (Leeds City Council, 2013).

\section{Major Events and Residents’ Support}

Considering that local community support for the development of an event is an important factor for its overall success, "a lack of coordination and cohesion within the host community can turn the planning process into a highly charged political and social exercise” (Gursoy \& Kendall, 2006, p. 605). Residents who consider tourism to be valuable and believe that benefits exceed the costs will be inclined to enter the exchange and consequently support the developmental process (Ap, 1992). As mentioned above, studies using SET test the relationships between positive/negative impacts and support (Nunkoo \& Ramkissoon, 2011), suggesting that "positive attitudes to tourism are usually accompanied by higher levels of support for the industry, while negative attitudes lead to lower support" (Nunkoo \& Gursoy, 2012, p. 246). All stakeholder involvement and support is critical, irrespective of their previous attitudes (Gursoy \& Kendall, 2006). This explains the importance for investors and organizers of considering the locals' perspectives and also involving them in decision making through community participation processes.

\section{Hypothesis Development}

Community Participation. Scholars widely argue and support the view that host community participation in tourism development is advantageous in terms of the sustainability and effectiveness of the implemented developmental policies (Lamberti et al., 2011).

Communities should take into account residents' attitudes and perceptions about its growth at the outset (Reid, Mair, \& George, 2004). The decision makers need to carefully introduce deliberate measures to enable indigenous people to take advantage of the opportunities brought by tourism or else the industry might lose host communities' support in a very gradual manner that may then threaten future development (Tosun, 2002). This indicates why "for any type of community development project, communities should be actively involved rather than only looking at the final outcome of community development projects” (Schulenkorf, 2010, p. 3).

In terms of events, a considerable amount of demand for financial and nonfinancial resources, and the direct and indirect engagement of all community members in their preparation and provision, represent a sufficient context in which to encourage stakeholder collaboration in tourism planning and development (Pappas, 2014). It is crucial for community participation to directly involve the stakeholders in decision making and/or by assessing benefits and costs for all stakeholders during the evaluation of the alternatives (Lamberti et al., 2011). Stakeholders and event planners are encouraged to cooperate because of the potential impact of events, beneficially overcoming the asymmetry that has hindered through time the diffusion of collaborative planning and community engagement. When communities actively participate in the management and design of planning and development in their locale, it ensures their support and a favorable attitude toward the implemented activities (Presenza, Del Chiappa, \& Sheehan, 2013). Based on empirical discussion of the literature, this study has developed the following hypothesis:

Hypothesis 1: Community participation has a direct positive influence on the support for hosting Leeds Pride.

The community must encourage people to work with each other and to develop a network in which everyone can contribute (Ife, 1995). Conversely, there are always people in a community who do not care about social projects, whereas there are others who do not have the time to participate (Creighton, 1995). Nevertheless, the appropriate integration of locals into joint projects has been shown to contribute to increased dedication of individuals and groups and also to increase the residents' support for further development and acceptance of positive impacts (Schulenkorf, 2010). On the contrary, the residents' support is likely to be affected by the perceived negative impacts (Kitnuntaviwat \& Tang, 2008). A lack of community participation may lead to a lack of support and, as a result, to an increase in negative perspectives with regard to further development, 
something that is of great importance because the success of tourism and events requires the host community's support (Gursoy \& Rutherford, 2004). This discussion has led to the development of the following hypotheses:

Hypothesis 2: There is a direct positive relationship between community participation and perceived benefits for Leeds Pride.

Hypothesis 3: There is a direct negative relationship between community participation and perceived costs for Leeds Pride.

Perceived Positive Impacts of Events. Residents and stakeholders share positive perceptions of the economic benefits of tourism (Holden, 2010). The improvement of the local economy through tourism (Gursoy \& Rutherford, 2004) contributes considerably to income and standard of living, and it creates investments and business development (Dyer, Gursoy, Sharma, \& Carter, 2007); thus, the economic impacts of tourism are the most valued elements for the host community (Nunkoo \& Gursoy, 2012). Dealing with culture and society, tourism (a) provides considerable opportunity for cultural exchanges between hosts and guests (Besculides, Lee, \& McCormick, 2002), (b) develops the potential for locals to be entertained (Andereck, Valentine, Knopf, \& Vogt, 2005), (c) creates flexible working patterns (Crompton \& Sanderson, 1990), (d) leads to heightened self-esteem (Stronza \& Gordillo, 2008), (e) improves the perceived quality of security through policing (Pizam, 1978), and (f) promotes cultural activities (Dyer et al., 2007).

Events are exceptionally useful for urban development and marketing plans due to their widespread recognition as tourist and place marketing investments, usually gained through publicly owned resources and having the considerable support of financial sponsors and partners (Getz, 2008). As Della Lucia (2013) suggested, “The effective allocation of financial resources and the optimization of their investment for urban growth and requalification purposes seem particularly important in this debt-burdened period of recession” (p. 91). Events draw significant numbers of visitors, attract sponsorship from television and corporations, and showcase the host location (Lee \& Taylor, 2005).
Several factors - such as the opportunity to promote products globally, to exploit new investment and business export opportunities, to optimize the knowledge of events management, and to increase the morale and pride of locals_-all motivate public involvement and corporate investments (Barney, Wenn, \& Martyn, 2002). The created “demand for goods and services from visitors to events and event organizers has a multiplicative effect on sales, production, income, added value and employment through the interdependence of the different sectors of the economic system” (Della Lucia, 2013, p. 92). In addition, events are "envisaged by policymakers as not only a global platform for place branding, but also ... . [as a] mechanism to accelerate the process of urban renewal” (Deng, 2013, p. 108). These findings lead to the following hypothesis:

Hypothesis 4: There is a direct positive relationship between perceived beneficial impacts and support for hosting Leeds Pride.

Perceived Negative Impacts of Events. Despite the perceived beneficial impacts of tourism, locals consider several negative effects emanating from tourism development. Economically, these include the increased price of goods, services, land, and property (Nunkoo \& Ramkissoon, 2011) as well as the lack of economic diversification (Jackson \& Inbarakan, 2006). In terms of culture and society, the costs of tourism include increased prostitution in the destination (Nunkoo \& Ramkissoon, 2011), vandalism, pressure on local services, change of local culture (Dyer et al., 2007), destruction of cultural and historical resources, psychological tension, and contributions to crime and substance abuse (Andereck et al., 2005). Environmentally, the perceived negative impacts include the destruction of the natural environment, increased environmental pollution (Nunkoo \& Ramkissoon, 2011), more litter, and the creation of traffic congestion and overcrowding (Dyer et al., 2007). Several studies indicate that the perceived costs to residents are negatively related to their support for tourism development (Gursoy, Chi, \& Dyer, 2010; Nunkoo \& Gursoy, 2012), whereas some others consider this relationship between the two constructs to be insignificant (Dyer et al., 2007; Gursoy \& Kendall, 2006). 
Events generate both positive and negative impacts, but negative impacts are usually ignored by locals mainly because of their perceived positive expectations, leading them to glorify the expected benefits (Kim, Gursoy, \& Lee, 2006). Events usually lead to an increase in taxes for structuring the facilities required and the mismanagement of public funds by organizers (Deccio \& Baloglu, 2002). Concerning society, events can have a negative influence on traditional family values (Kousis, 1989), increase the commercialization of culture, and damage the reputation of locals because of the existence of poor facilities and improper practices (Ritchie, 1984). In terms of the environment, if the urban development caused by events is not carefully planned, it can lead to several consequences, "including overcapacity, functional obsolescence, maintenance difficulties, and extra cost for regeneration in the long term” (Deng, 2013, p. 108). Evaluating these findings, I developed the following hypothesis:

Hypothesis 5: There is a direct negative relationship between perceived negative impacts and support for hosting Leeds Pride.

\section{The Proposed Model}

SET is considered to be one of the most widely used frameworks by researchers attempting to study community (Lee, Kang, Long, \& Reisinger, 2010). SET is "a general sociological theory concerned with understanding the exchange of resources between individuals and groups in an interaction situation” (Ap, 1992, p. 668). In tourism, SET implies that the support of locals is based on their evaluations of the costs and benefits resulting from the industry (Andereck et al., 2005). From a theoretical perspective, residents who view large scale tourism projects as contributory support the process when they perceive that benefits/rewards exceed costs (Turner, 1986), but these perceptions of potential impacts depend on how people evaluate the exchange in which they are involved (Gursoy \& Kendall, 2006).

Reid et al. (2004) suggested that "tourismdominated communities should plan their evolution more systematically, thereby taking into account residents' attitudes and perceptions about its growth at the outset” (p. 624). Other authors, such as Lewis (1998), have perceived that communities can undertake planning participation in an effort to offset some of the more negative impacts, and important strides have been made toward understanding this process. Even if SET remains one of the most acceptable frameworks for studying community support, some question its predictive power (Nunkoo \& Gursoy, 2012). Still, the implementation of SET in events seems endless (Deccio \& Baloglu, 2002; Pappas, 2014). As Nunkoo and Ramkissoon (2011) suggested, "tests of the SET, as well as its application by researchers investigating residents' attitudes have been based on an incomplete specified set of ideas, leaving out important theoretical constructs relevant to the theory" (p. 966); thus, it requires adequate integration into research on community responses to tourism.

Figure 1 presents this study's test model, which has its theoretical basis in SET and builds on previous research. Initially, the model suggests that actual participation influences the perception of community participation. It basically proposes that the support of major events (with special reference to Leeds Pride) is influenced by the degree of community participation and the perceived positive and negative impacts. The model further indicates that the potential costs and benefits can operate as a moderator on community participation and final support from the locals.

\section{Methodology}

\section{Characteristics}

The research questionnaire consists of 18 statements on a 7-point Likert scale $(1=$ strongly disagree, 7 = strongly agree) as well as one question about community participation, evaluation of overall (positive/negative) impacts, and community support for Leeds Pride. On the basis of the literature review and research framework, the questionnaire comprises five parts: (1) community participation (seven statements) and examination of actual participation (one question), (2) perceived costs of Leeds Pride (four statements), (3) perceived benefits of Leeds Pride (four statements), (4) community support for Leeds Pride (three statements), and (5) demographic characteristics of residents (gender, age, location of residence). The statements dealing with community participation were 


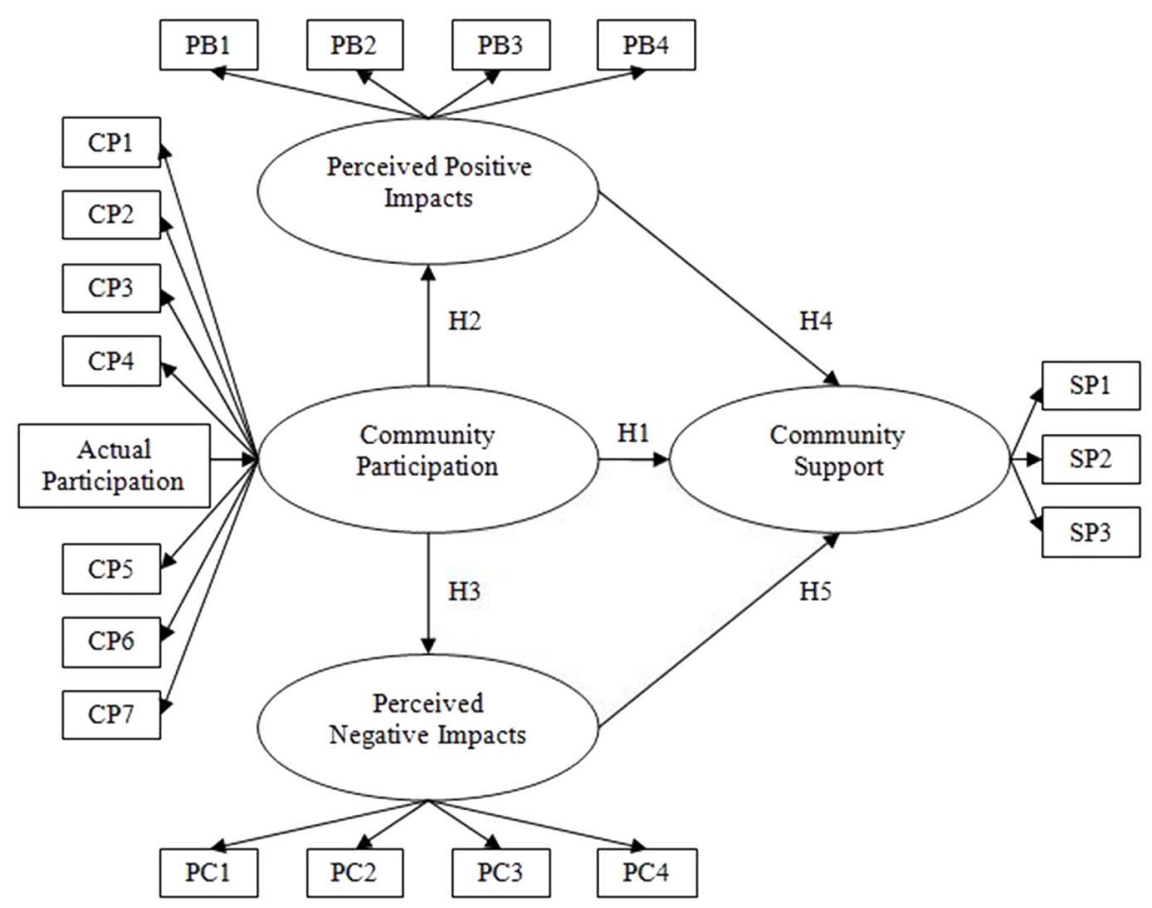

Figure 1. The proposed model. $\mathrm{PB}=$ perceived benefits; $\mathrm{CP}=$ community participation; PC = perceived costs; SP = support of Leeds Pride.

adopted from Reid et al. (2004). The other 11 statements were adopted from Gursoy and Kendall (2006). The research was conducted in November 2012, and I focused on adult Leeds residents living in the city for at least the last 3 years, thus ensuring their experience of the event's impacts and also the potential for their involvement in community participation processes.

Reid et al. (2004) suggested that communities acknowledge the importance of decision making involvement and support their engagement for further development. Moreover, the same study indicates that community participation is not only dependent on locals' agreement for further development and willingness to participate in decision making but also on the perspectives regarding the processes for problem solving as well as implemented promotional activities affecting the destination. Conversely, the extent that locals perceive that an event will have a beneficial impact to the host community influences their overall support (Gursoy \& Kendall, 2006). The community support for organized events is further influenced by the extent that the residents believe that events improve their recreational facilities (Allen, Hafer, Long, \& Perdue, 1993), their cultural and shopping opportunities, and the way they finally promote the destination (Deccio \& Baloglu, 2002).

The respondents were selected at the two major transport stations in Leeds (Leeds City Bus Station/ Central Coach Station; Leeds Railway Station). The recruitment of participants in communal areas is a usual practice for researchers in order to reduce the survey bias, as long as the dispersion of sites is sufficient to analogically cover the examined population (Pappas, 2014). The respondents were selected through purposive sampling combined with random sampling. More specifically, the two sites (Leeds City Bus Station/Central Coach Station; Leeds Railway Station) were selected because these are the main communal areas in Leeds, where the event takes place (purposive). The respondents were randomly selected at the city center where they were living, according to their individual characteristics 
(age, place, and length of residency), and then questionnaires were administered.

\section{Sample Determination and Collection}

Appropriate representation was a fundamental criterion in order to determine the sample amount. When there are unknown population proportions, the researcher should choose a conservative response format of $50 \% / 50 \%$ (i.e., that $50 \%$ of the respondents have negative perceptions, and 50\% have not) to determine the sample size (Akis, Peristianis, \& Warner, 1996). A confidence limit of at least $95 \%$ and a 5\% sampling error were selected. The sample size was as follows:

$$
\begin{aligned}
N & =\frac{(t-\text { table })^{2}(\text { hyphothesis })}{S^{2}} \Rightarrow N=\frac{(1.96)^{2}(0.5)(0.5)}{(0.5)^{2}} \\
& \Rightarrow N=384.16, \text { which is rounded to } 400 .
\end{aligned}
$$

The calculation of the sampling size is independent of the total population size; hence, the sampling size determines the error (Aaker \& Day, 1990). Two hundred usable questionnaires were completed in each transport station, filling in a total of 400 .

\section{Data Analysis}

To analyze the collected data, I used SPSS (Version 17.0). For descriptive statistics, the analysis used means, distributions, and standard deviations. There is also an elaboration of data through factor analysis. Probability analysis was used for the examination of the influence of actual participation on community participation, whereas factor analysis was implemented for the dependent variables. Multiple regression was used to investigate the influential extent of community participation and impact constructs to the support of Leeds Pride as well as the relationships toward community participation and overall costs and benefits. The validity and reliability of the research and components were examined using Kaiser-Mayer-Olkin (KMO)-Bartlett, varimax rotation loadings, and Cronbach's alpha while a structural equation model (SEM) was implemented. MPlus was used for SEM analysis. The results were considered significant at the 0.05 level of confidence. Cross tabulations were employed for the presentation of research findings.

\section{SEM and Model Fit}

As Gross and Brown (2008) suggested, the multivariate statistical analysis of SEM is capable of measuring the concepts and the paths of hypothesized relationships between concepts. According to Wang and Wang (2012), when using MPlus, it is best to measure the grouping variables as continuous and also to measure those assessed through a 5-point (or more) Likert scale in this way, although they are in fact ordered categorical measures. Thus, the study measured the variables as continuous. A two-step approach was adopted. The first part dealt with the assessment of the factor structure of each of the measurement models through confirmatory factor analysis (CFA). The examined constructs for the determination of model fit were as follows: community participation, perceived positive and negative impacts, and community supportincluding actual participation. Then, the complete structural model was examined for the identification of causal relationships among the constructs and the determination of structural model fit.

For model fit, the research followed the study of Gross and Brown (2008). First, it examined the relationships between the variables, and then it evaluated the standardized coefficients for the regression paths. The critical ratio (cr) was used for the examination between path and constructs, falling outside \pm 1.96 , but the examination of standardized residuals did not identify any possible item for respecification or deletion. The most common measure of SEM fit is the probability of the chi-square statistic (Martens, 2005). According to Schermelleh-Engel, Moosbrugger, and Müller (2003), a good fit is provided if $0 \leq \chi^{2} / d f \leq 2$. Other model fit indices were also used in the analysis. These were as follows: (a) the comparative fit index (CFI), which specifies no relationships among variables, indicates a better fit when closer to 1.0; (b) the root-mean-square error of approximation (RMSEA) of 0.05 or less reflects a model of close fit; and (c) the standardized rootmean-square residual (SRMR), which is the square root of the discrepancy between the sample covariance matrix and the model covariance matrix, should be less than 0.08 .

As recommended by Kline (2010) through several options, these four (chi-square, CFI, RMSEA, and SRMR) are the most appropriate for the examination 
and evaluation of model fit. The results of CFA have shown that $\chi^{2}(349)=731.40, p<0.01$. Consequently, the $\chi^{2} / d f$ ratio $=1.93$, providing a good fit. The rest model fit indicators were CFI $=0.91$, RMSEA $=0.05$, and SRMR $=0.08(p<0.01)$. These results indicate a good model fit.

\section{Findings}

\section{Profile of the Respondents}

The sample consisted of 400 people. Concerning actual participation, 58 respondents (14.5\%) stated that they had participated in the organization and community discussions and decision making about Leeds Pride, whereas the remaining 342 (85.5\%) had not. With regard to gender, 188 were men (47\%), and 212 were women (53\%). In terms of age, 137 respondents (34.25\%) were between 18 and 35 years of age, 161 people (40.25\%) were between 36 and 50 years of age, and 102 respondents $(25.5 \%)$ were more than 50 years of age. The distribution of respondents according to their area of residence was fairly good because 104 of them (26\%) were living in the northern parts of Leeds, 105 (26.25\%) were living in the southern areas, 118 (29.5\%) were living in eastern Leeds, and the remaining 73 respondents (18.25\%) were living in western areas of the city.

\section{Data Analysis}

In the statements focusing on community participation (see Table 1), the research indicates positive trends with respect to aspects of willingness to promote Pride's success (6.03), locals' involvement in further tourism development (5.63), the need for further tourism development (5.48), and participation in further decision making (5.35). The respondents seem to agree on the beneficial economic impacts of Leeds Pride (5.08). An agreement on negative social and cultural impacts also exists (4.33 and 4.08, respectively), whereas the trend is higher for beneficial social and cultural impacts (4.67 and 4.84, respectively). Respondents agreed strongly with all statements that dealt with the support of Leeds Pride (SP1, SP2, and SP3).

Concerning factor analysis, there was an effort to focus on the important components of the research (see Table 2). Thus, for higher coefficients, absolute values of less than 0.4 were suppressed. The correlation matrix revealed numbers larger than 0.4 over numerous statements. The KMO of sampling adequacy was 0.729 (higher than the minimum requested 0.6 for further analysis), whereas statistical significance also existed $(p<0.01)$. In order to examine whether several items that propose to measure the same general construct produce similar scores (internal consistency), the researcher obtained Cronbach's alpha, where the overall reliability was 0.766 , and all variables scored more than 7 (minimum value 7; Nunnally, 1978). I also performed CFA to establish validity in the examined variables. With the exception of three variables, all the others scored more than 0.4 , which is the minimum acceptable value (Norman \& Streiner, 2008). The validity and reliability analysis, and the relation to each other, are highlighted in Table 3.

The examination of the above components revealed that the total $R^{2}=32.6$ (see Fig. 2). The relatively low result indicates the necessity for further research introducing more areas of investigation. Regression analysis was statistically significant according to analysis of variance $(p<0.01)$. Two out of three components produced statistical significance: community participation $(p>0.05)$, perceived positive impacts $(p<0.05)$, and perceived negative impacts $(p<0.01)$. The standardized coefficients confirmed that actual participation and engagement in the event's decision making and organization have an important impact $(\beta=0.31$, $p<0.05$ ) on the formulation of the actual perceptions of community participation. In addition, the primary factor affecting residents' support of the event was the perceived benefits of Leeds Pride ( $\beta=0.28, p<0.01$ ), followed by the reverse outcome of the perceived costs $(\beta=-0.25, p<0.05)$, whereas community participation did not seem to directly affect locals' support because it did not produce any statistical significance $(\beta=0.15$, $p>0.05)$.

On the other hand, findings suggest that community participation has a moderating influence on the above components, having a relatively high importance among the perceived impacts. The higher influence was community participation with perceived benefits $(\beta=0.32, p<0.01)$, 
Table 1

Descriptive Statistics

\begin{tabular}{|c|c|c|c|c|c|}
\hline No. & Statement & $M$ & $S D$ & Skewness & Kurtosis \\
\hline $\mathrm{CP} 1$ & $\begin{array}{l}\text { Concerning Leeds Pride, there is a clear pro- } \\
\text { cess of solving problems as they arise. }\end{array}$ & 4.7 & 1.53 & -0.40 & -1.14 \\
\hline CP2 & $\begin{array}{l}\text { Residents want further tourism development } \\
\text { through Leeds Pride. }\end{array}$ & 5.5 & 1.02 & -0.61 & 0.17 \\
\hline СР3 & $\begin{array}{l}\text { Residents are in agreement on how Leeds Pride } \\
\text { has developed. }\end{array}$ & 4.7 & 1.41 & -0.15 & -1.50 \\
\hline CP4 & $\begin{array}{l}\text { Most residents are willing to participate in fur- } \\
\text { ther tourism decision making for Leeds Pride. }\end{array}$ & 5.4 & 1.00 & -0.21 & -0.72 \\
\hline CP5 & $\begin{array}{l}\text { Most residents would be willing to attend a } \\
\text { community meeting to discuss an important } \\
\text { tourism issue for Leeds Pride. }\end{array}$ & 4.8 & 0.98 & -0.39 & -0.46 \\
\hline CP6 & $\begin{array}{l}\text { Every citizen of Leeds needs to be involved in } \\
\text { further tourism development through Leeds } \\
\text { Pride. }\end{array}$ & 5.6 & 0.75 & 0.13 & 0.31 \\
\hline CP7 & $\begin{array}{l}\text { Leeds citizens are willing to promote the suc- } \\
\text { cess of the pride event. }\end{array}$ & 6.0 & 0.78 & -0.14 & -1.09 \\
\hline PC1 & $\begin{array}{l}\text { Overall, Leeds Pride will have negative eco- } \\
\text { nomic impacts. }\end{array}$ & 3.1 & 1.09 & 1.39 & 2.07 \\
\hline PC2 & $\begin{array}{l}\text { Overall, Leeds Pride will have negative social } \\
\text { impacts. }\end{array}$ & 4.3 & 1.19 & 0.12 & -1.09 \\
\hline PC3 & $\begin{array}{l}\text { Overall, Leeds Pride will have negative cul- } \\
\text { tural impacts. }\end{array}$ & 4.1 & 0.87 & -0.14 & -0.66 \\
\hline PC4 & $\begin{array}{l}\text { Overall, Leeds Pride will have negative envi- } \\
\text { ronmental impacts. }\end{array}$ & 4.6 & 0.85 & -0.27 & 0.20 \\
\hline PB1 & $\begin{array}{l}\text { Overall Leeds Pride will have positive eco- } \\
\text { nomic impacts }\end{array}$ & 5.1 & 0.95 & 0.21 & -0.80 \\
\hline PB2 & $\begin{array}{l}\text { Overall, Leeds Pride will have positive social } \\
\text { impacts. }\end{array}$ & 4.7 & 0.11 & -0.30 & -0.42 \\
\hline PB3 & $\begin{array}{l}\text { Overall, Leeds Pride will have positive cultural } \\
\text { impacts. }\end{array}$ & 4.8 & 1.43 & -0.45 & -0.56 \\
\hline PB4 & $\begin{array}{l}\text { Overall, Leeds Pride will have positive envi- } \\
\text { ronmental impacts. }\end{array}$ & 4.9 & 0.92 & -0.04 & -0.31 \\
\hline SP1 & $\begin{array}{l}\text { Leeds Pride will promote the development of } \\
\text { visitor services (i.e., hotels, restaurants). }\end{array}$ & 5.5 & 0.96 & -1.00 & 0.96 \\
\hline SP2 & $\begin{array}{l}\text { Leeds Pride will promote the development of } \\
\text { information services for visitors (i.e., maps, } \\
\text { guidebooks). }\end{array}$ & 5.1 & 0.89 & 0.11 & -1.05 \\
\hline SP3 & $\begin{array}{l}\text { Leeds Pride will help the promotion of Leeds } \\
\text { as an event destination. }\end{array}$ & 5.9 & 0.92 & -0.96 & 1.54 \\
\hline
\end{tabular}

and the lower one was community participation with perceived costs $(\beta=0.24, p<0.05)$. As the results indicate, even if there is no direct influential factor of community participation, its influence on impacts (in both benefits and costs) is relatively high in terms of local support for Leeds Pride.

The research model partially explains the study's endogenous variables: community participation $\left(R^{2}=0.31\right)$, perceived benefits $\left(R^{2}=0.29\right)$, and perceived costs $\left(R^{2}=0.20\right)$. The results suggest that this model is a relatively good method of evaluating the importance of the examined factors affecting community support in major events with special reference to Leeds Pride.

\section{Discussion}

The findings indicate that the citizens of Leeds support the Pride event in their city, focusing on its success and the beneficial impacts it will have on both the destination and its residents. Moreover, the engagement of locals in the decision making influences the expressed perceptions of the importance of community participation. The research also confirms this support through the considerably 
Table 2

Cronbach's Alpha and Factor Analysis Loadings

\begin{tabular}{|c|c|c|c|c|c|}
\hline \multirow[b]{2}{*}{ Statement } & \multicolumn{4}{|c|}{ Loadings } & \multirow[b]{2}{*}{ Cronbach's $\alpha$} \\
\hline & $\begin{array}{l}\text { Community } \\
\text { Participation }\end{array}$ & $\begin{array}{l}\text { Perceived Costs } \\
\text { From Pride }\end{array}$ & $\begin{array}{l}\text { Perceived Benefits } \\
\text { From Pride }\end{array}$ & $\begin{array}{l}\text { Support of Leeds } \\
\text { Pride }\end{array}$ & \\
\hline CP1 & 0.40 & & & & 0.76 \\
\hline CP2 & 0.69 & & & & 0.76 \\
\hline CP3 & 0.49 & & & & 0.77 \\
\hline CP4 & 0.74 & & & & 0.77 \\
\hline $\mathrm{CP} 5^{\mathrm{a}}$ & & & & & 0.76 \\
\hline CP6 & 0.68 & & & & 0.77 \\
\hline CP7 & 0.63 & & & & 0.77 \\
\hline PC1 & & 0.45 & & & 0.76 \\
\hline $\mathrm{PC} 2^{\mathrm{b}}$ & & & & & 0.76 \\
\hline PC3 & & 0.47 & & & 0.77 \\
\hline PC4 & & 0.68 & & & 0.77 \\
\hline $\mathrm{PB}^{\mathrm{c}}$ & & & & & 0.76 \\
\hline PB2 & & & 0.79 & & 0.76 \\
\hline PB3 & & & 0.62 & & 0.76 \\
\hline PB4 & & & 0.77 & & 0.76 \\
\hline SP1 & & & & 0.71 & 0.77 \\
\hline SP2 & & & & 0.65 & 0.77 \\
\hline SP3 & & & & 0.68 & 0.78 \\
\hline $\begin{array}{l}\text { Total rotation sums } \\
\text { of squared loadings }\end{array}$ & 3.25 & 2.41 & 2.89 & 1.21 & \\
\hline $\begin{array}{l}\% \text { of total variance } \\
\text { explained }\end{array}$ & 18.07 & 7.82 & 10.49 & 6.72 & \\
\hline
\end{tabular}

${ }^{\mathrm{a}}$ Eliminated from factor analysis/low commonality (score $\left.=0.38\right) .{ }^{\mathrm{b}}$ Eliminated from factor analysis/low commonality $($ score $=0.27)$.

'Eliminated from factor analysis/low commonality (score $=0.23)$.

higher proportion of perceived positive impacts in comparison with the perceived negative impacts, also in agreement with previous studies such as Gursoy and Kendall (2006) and Nunkoo and Gursoy (2012). The exceptionally high levels of agreement in terms of the willingness of locals to promote the success of Leeds Pride (CP7), their need for involvement in further tourism development through Leeds Pride (CP6), the necessity for further tourism development (CP2), and their willingness to participate in further tourism decision making (CP4) reveal a vibrant community that wants to have the highest possible participation in further development and considerable involvement in the decision-making process.

Community participation does not seem directly to influence the community support of events hosted in Leeds. On the contrary, its influence on the perceptions of positive and negative impacts is relatively high, because these perspectives determine the locals' final stance. This is in agreement with previous studies by Andereck et al. (2005),
Gursoy and Kendall (2006), and Turner (1986). More importantly, because community participation is viewed positively and locals greatly appreciate this opportunity, the influence on the perceived benefits is much higher than on the perceived costs. The findings contribute to the understanding of community participation's role in major local events.

Because the involvement of community participation in decision making and the planning of events increase locals' support even if this comes as a moderating effect, the decision makers need

Table 3

Validity and Reliability Analysis

\begin{tabular}{lcc}
\hline Measure & Result & Relationship \\
\hline Composite reliability (CR) & 0.74 & CR $>0.7$ \\
Average variance extracted (AVE) & 0.59 & AVE $>0.5$ \\
Maximum shared variance (MSV) & 0.55 & MSV $<$ AVE \\
Average shared variance (ASV) & 0.50 & ASV $<$ AVE \\
\hline
\end{tabular}




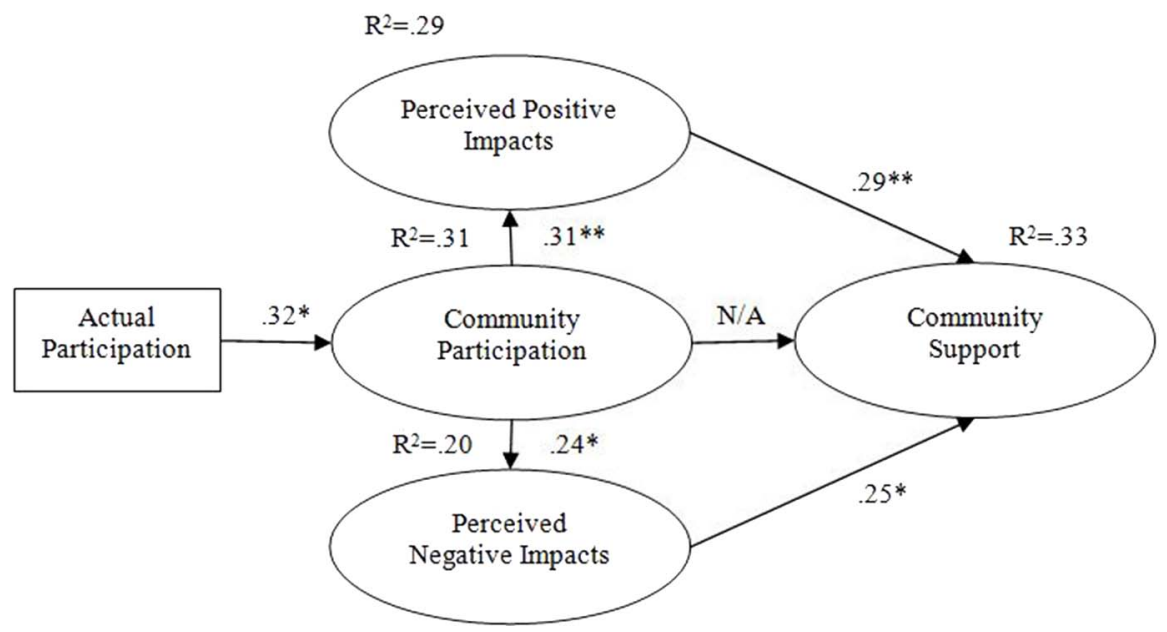

Figure 2. The influential factors of community support for Leeds pride. *Coefficient is significant at 0.05 level. ${ }^{* *}$ Coefficient is significant at 0.01 level.

to increase the potential for locals' involvement in the planning process. The research also indicates that, concerning community participation, the lowest respondent trends occurred for the statements focusing on the clear process of solving problems as they arise (CP1) and the agreement of residents on how Leeds Pride has developed (CP3). These low participation issues were also mentioned by previous research (Haxton, 1999). Thus, the findings strengthen our understanding about the influential extent of community participation in community's perceptions.

The host community's support can continue after the event and can strengthen through increased participation, also leading to the greater success of repeated events in the future. The importance of increased community participation is also stressed by previous research (Reid et al., 2004) and is underlined as the pathway to greater success (Schulenkorf, 2010). The findings confirm this aspect, because a high respondent rate expressed a favorable attitude toward further tourism development as a result of Leeds Pride (CP2). Results also showed that respondents indicate a highly positive perceived influence of Leeds Pride on the economy (PB1) and of their connection with the significant influence of community participation on the perceived benefits. This finding further contributes to the relationship of community participation and perceived impacts with residents' support.
Despite the research contribution, there are limitations. First, one must consider carefully the general nature of the research because some issues — such as the destination brand name (very strong in the case of Leeds), national economic and business environment, and the local community's societal and cultural background-can produce different outcomes. Second, the research did not examine aspects such as tourist perceptions and the local tourism and hospitality industry's involvement in decision making.

\section{Managerial Implications}

The development of events can strengthen the evolution of the community as a whole. Still, the engagement of locals in decision making remains a crucial factor for the success of these events while it also ensures their acceptance from locals. Decision makers still have much to do to widen planning and development involvement to more stakeholder groups, because all of them should be involved. The event planners can further advertize the importance of community involvement and further clarify the problem-solving process they implement, develop decision-making focus groups for the event, further encourage participation through e-initiatives (e.g., creation of participation through e-platforms), and expand the inclusion of locals in managerial aspects (e.g., participation in operational issues of Leeds pride). 
Event organizers also have to consider local involvement during the postevent period. If the local community is engaged in decision processes for further planning and development, it is more likely to achieve higher local involvement and satisfaction and to have greater future potential for organizing successful events. Thus, decision makers can provide an annual evaluation of the event from locals with online participation and through primary research initiatives. The organizers can exploit the willingness of locals to further participate and engage in an event they consider successful, as the findings of the study indicated.

\section{Conclusion}

Local participation in event decision making is significantly important for the success of the events and further tourism development. Even if the direct influence of community participation on final support for the event is not very high, the extent of its influence on the event's perceived benefits and costs is crucial to the ultimate determination of community perceptions. Locals are willing to support further tourism development and to organize events and also to contribute to their success, something that can be ensured to a great extent through their participation in decision making in further planning processes.

The contribution of this article is that it focuses on community support and the importance of the expected benefits and costs. It correlates community participation and impacts with residents' support, and it reveals its importance in the formulation of perceived impacts. It also reveals the influential extent of the relationship between the actual engagement of locals in decision making and the perspectives of community participation. This article also contributes to the theoretical domain through the investigation of residents' participation in decision making and by explaining locals' support for major events, focusing on Leeds Pride. Methodologically, even if the linear (regression) analysis provides substantial information for the perceptions of the respondents, the complexity of response formulation is advisable to be further investigated. In this case, nonlinear techniques such as qualitative comparative analysis and conjoint analysis can be implemented. This addition can provide a spherical examination for the creation and change of the expressed perceptions.

Researchers expect that the effects of the successful organization of Leeds Pride will be significant, at least in the near future. From this perspective, it would be useful if one could repeat this research over time to examine the variation in locals' perceptions as Leeds Pride evolves year by year. Also, further research into tourism and hospitality enterprises in Leeds in accordance with their role and involvement with Leeds Pride decision making would be useful. Such analysis could provide a more complete understanding of the formulation of enterprising perspectives and opinions regarding major events.

\section{References}

Aaker, D., \& Day, G. (1990). Marketing research. New York, NY: Wiley.

Akis, S., Peristianis, N., \& Warner, J. (1996). Residents’ attitudes to tourism development: The case of Cyprus. Tourism Management, 17(7), 481-494.

Allen, L., Hafer, H., Long, R., \& Perdue, R. (1993). Rural residents' attitudes toward recreation and tourism development. Journal of Travel Research, 31(4), 27-33.

Andereck, K. L., Valentine, K. M., Knopf, R. C., \& Vogt, C. A. (2005). Residents' perceptions of community tourism impacts. Annals of Tourism Research, 32(4), 1056-1076.

Ap, J. (1992). Residents' perceptions on tourism impacts. Annals of Tourism Research, 19(4), 665-690.

Barney, R., Wenn, S., \& Martyn, S. (2002). Selling the five rings: The international Olympic committee and the rise of Olympic commercialism. Salt Lake City: University of Utah Press.

Besculides, A., Lee, M. E., \& McCormick, P. J. (2002). Residents' perceptions of the cultural benefits of tourism. Annals of Tourism Research, 29(2), 303-319.

Carmody, S. (2012, August 6). Leeds Pride huge success. Diva Magazine. Retrieved from http://www.divamag. co.uk/category/lifestyle/leeds-pride-2012.aspx

City Mayors. (2012). The UK's 200 largest towns, cities and districts. Retrieved from http://www.citymayors.com/ gratis/uk_topcities.html

Creighton, J. L. (1995). Trends in the field of public participation in the United States. Interact: The Journal of Public Participation, 1(1), 7-23.

Crompton, R., \& Sanderson, K. (1990). Gendered jobs and social change. London, UK: Unwin Hyman.

Deccio, C., \& Baloglu, S. (2002). Nonhost community resident reactions to the 2002 Winter Olympics: The spillover impacts. Journal of Travel Research, 41(1), 46-56.

Della Lucia, M. (2013). Economic performance measurement systems for event planning and investment decision making. Tourism Management, 34, 91-100. 
Deng, Y. (2013). Conceptualising mega events flagships: A case study of China pavilion of Expo 2010 Shanghai China. Frontiers of Architectural Research, 2(1), 107-115.

Dyer, P., Gursoy, D., Sharma, B., \& Carter, J. (2007). Structural modeling of resident perceptions of tourism and associated development on the Sunshine Coast, Australia. Tourism Management, 28(2), 409-422.

Fourie, J., \& Gallego, M. S. (2011). The impact of megasport events on tourism arrivals. Tourism Management, 32(6), 1364-1370.

Getz, D. (2008). Event tourism: Definition, evolution, and research. Tourism Management, 29, 403-428.

Grant, M. (2004). Innovation in tourism planning process: Action learning to support a coalition of stakeholders for sustainability. Tourism and Hospitality Planning and Development, 1(3), 219-237.

Gross, M. J., \& Brown, G. (2008). An empirical structural model of tourists and places: Progressing involvement and place attachment into tourism. Tourism Management, 29, 1141-1151.

Gursoy, D., Chi, C. G., \& Dyer, P. (2010). Locals’ attitudes toward mass and alternative tourism: The case of Sunshine Coast, Australia. Journal of Travel Research, 49(3), 381-394.

Gursoy, D., \& Kendall, K. W. (2006). Hosting mega events: Modelling locals support. Annals of Tourism Research, 33(3), 603-623.

Gursoy, D., \& Rutherford, D. (2004). Host attitudes toward tourism: An improved structural modelling approach. Annals of Tourism Research, 31(3), 495-516.

Haxton, P. A. (1999). Community involvement and the Olympic games: A review of related research. Paper presented at the 7th International Post Graduate Seminar on Olympic Studies, Greece. Retrieved from http://www.geoci ties.ws/olympic_seminar7/papers/haxton.htm

Holden, A. (2010). Exploring stakeholders' perceptions of sustainable tourism development in the Annapurna conservation area: Issues and challenge. Tourism and Hospitality Planning and Development, 7(4), 337-351.

Ife, J. W. (1995). Community development: Creating community alternatives - Vision, analysis and practice. Melbourne, Victoria, Australia: Longman Australia.

Jackson, M. S., \& Inbarakan, R. J. (2006). Evaluating residents’ attitudes and intentions to act toward tourism development in regional Victoria, Australia. International Journal of Tourism Research, 8(5), 355-366.

Kim, H. J., Gursoy, D., \& Lee, S. B. (2006). The impact of the 2002 World Cup on South Korea: Comparisons of preand post-games. Tourism Management, 27(1), 86-96.

Kitnuntaviwat, V., \& Tang, J. (2008). Residents’ attitudes, perception and support for sustainable tourism development. Tourism and Hospitality Planning and Development, 5(1), 45-60.

Kline, R. B. (2010) Principles and practice for structural equation modelling. New York, NY: Guilford Press.

Kousis, M. (1989). Tourism and the family in a rural Cretan community. Annals of Tourism Research, 6(3), 318-332.
Kruger, E. A., \& Heath, E. T. (2013). Along came a mega-event: Prospects of competitiveness for a 2010 FIFA World Cup ${ }^{\mathrm{TM}}$ host city. Current Issues in Tourism, 16(6), 570-590.

Lamberti, L., Noci, G., Guo, J., \& Zhu, S. (2011). Megaevents as drivers for community participation in developing countries: The case of Shanghai World Expo. Tourism Management, 32(6), 1474-1483.

Lee, C., Kang, S. K., Long, P., \& Reisinger, Y. (2010). Residents' perceptions of casino impacts: A comparative study. Tourism Management, 31(2), 189-201.

Lee, C., \& Taylor, T. (2005). Critical reflections on the economic impact assessment of a mega-event: The case of 2002 FIFA World Cup. Tourism Management, 26(4), 595-603.

Leeds City Council. (2006). Community engagement policy. Leeds, UK: Corporate Communications.

Leeds City Council. (2009). The Leeds agenda for improved economic performance. Leeds, UK: Author.

Leeds City Council. (2013). Leeds growth strategy: Getting Leeds working. Leeds, UK: Author.

Leeds City Region. (2012). Quarterly economic surveyThird quarter 2012. Leeds, UK: Author.

Leeds Pride. (2012). About Leeds Pride. Retrieved from http://www.leedspride.com

Lewis, J. (1998). A rural tourism development model. Tourism Analysis, 2, 91-105.

Martens, M. P. (2005). The use of structural equation modeling in counseling psychology research. The Counseling Psychologist, 33(3), 269-298.

Norman, G., \& Streiner, D. (2008). Biostatistics: The bare essentials (3rd ed.). Hamilton, Ontario, Canada: Decker.

Nunkoo, R., \& Gursoy, D. (2012). Residents support for tourism: An identity perspective. Annals of Tourism Research, 39(1), 243-268.

Nunkoo, R., \& Ramkissoon, H. (2011). Developing a community support model for tourism. Annals of Tourism Research, 38(3), 964-988.

Nunnally, J. C. (1978). Psychometric theory (2nd ed.). New York, NY: McGraw-Hill.

Pappas, N. (2014). Hosting mega events: Londoners' support of the 2012 Olympics. International Journal of Hospitality and Tourism Management, 21, 10-17.

Peng, Q., Cheng, L., \& Qin, H. (2013). The impacts of large scale exhibitions on hotel room rates: A case study of Canton Fair. Tourism Economics, 19(2), 245-256.

Pizam, A. (1978). Tourism's impacts: The social costs of the destination community as perceived by its residents. Journal of Travel Research, 16(4), 8-12.

Presenza, A., Del Chiappa, G., \& Sheehan, L. (2013). Residents' engagement and local tourism governance in maturing beach destinations: Evidence from an Italian case study. Journal of Destination Marketing \& Management, 2(1), 22-30.

Reid, D. G., Mair, H., \& George, W. (2004). Community tourism planning: A self-assessment instrument. Annals of Tourism Research, 31(3), 623-639.

Ritchie, J. (1984). Assessing the impact of hallmark events: Conceptual and research issues. Journal of Travel Research, 22(1), 2-11. 
Schermelleh-Engel, K., Moosbrugger, H., \& Müller, H. (2003). Evaluating the fit of structural equation models: Test of significance and descriptive goodness-of-fit measures. Methods of Psychological Research-Online, 8(2), 23-74.

Schulenkorf, N. (2010). Community empowerment through sport and events: A conceptual framework for sport-fordevelopment projects. Leeds, UK: Global Events Congress.

Stevenson, N., Airey, D., \& Miller, G. (2008). Tourism policy making: The policymakers' perspectives. Annals of Tourism Research, 35(3), 732-750.

Stokes, R. (2008). Tourism strategy making: Insights to the events tourism domain. Tourism Management, 29(2), 252-262.

Stronza, A., \& Gordillo, J. (2008). Community views of ecotourism. Annals of Tourism Research, 35(2), 448-468.

Tosun, C. (2002). Host perceptions of impacts: A comparative tourism study. Annals of Tourism Research, 29(1), 231-253.
Turner, J. H. (1986). The structure of sociological theory. Chicago, IL: Dorsey Press.

Van Niekerk, M. (2014). Advocating community participation and integrated tourism development planning in local destinations: The case of South Africa. Journal of Destination Marketing and Management, 3(2), 82-84.

Virtual Tourist. (2012, December 10). Leeds things to do. Retrieved from http://www.virtualtourist.com/travel/Eur ope/United_Kingdom/England/West_Yorkshire/Leeds309936/Things_To_Do-Leeds-TG-C-1.html

VisitBritain. (2013). Delivering a golden legacy: A growth strategy for inbound tourism to Britain from 2012 to 2020. London, UK: Author.

Wang, J., \& Wang, R. (2012). Structural equation modelling: Applications using MPlus. Chichester, UK: Wiley.

Zhao, W., \& Ritchie, J. R. B. (2008). Tourism and poverty alleviation: An integrated research framework. Current Issues in Tourism, 10(2-3), 119-143. 